\title{
Correlations between ANP concentrations in atria, plasma and cerebral structures and sodium chloride preference in Wistar rats
}

\author{
H. Glass ${ }^{1}$, \\ J. Gutkowska \\ A.L.V. Favaretto ${ }^{1}$ and \\ J. Antunes-Rodrigues ${ }^{1}$
}

\author{
1Departamento de Fisiologia, Faculdade de Medicina de Ribeirão Preto, \\ Universidade de São Paulo, 14049-900 Ribeirão Preto, SP, Brasil \\ ${ }^{2}$ Centre de Recherche, Hôtel-Dieu de Montréal, Montréal PQ, H2W 1T8 Canada
}

\author{
Correspondence \\ H. Glass \\ Departamento de Fisiologia \\ Faculdade de Medicina de Ribeirão \\ Preto \\ 14049-900 Ribeirão Preto, SP \\ Brasil \\ Fax: 55 (016) 633-0017 \\ E-mail:mlglass@usp.br \\ helglass@usp.br \\ Presented at the XI Annual Meeting \\ of the Federação de Sociedades de \\ Biologia Experimental, Caxambu, \\ MG, Brasil, August 21-24, 1996. \\ Research supported by the \\ National Institutes of Health \\ (NIH Nos. DK-10073 and DK-43900), \\ FAPESP (No. 91/0567-0) and \\ CNPq (No. 50167/91-7) to \\ J. Antunes-Rodrigues. H. Glass \\ was the recipient of a CAPES \\ fellowship.
}

Received April 18, 1996

Accepted October 22, 1996

\begin{abstract}
We determined whether ANP (atrial natriuretic peptide) concentrations, measured by radioimmunoassay, in the ANPergic cerebral regions involved in regulation of sodium intake and excretion and pituitary gland correlated with differences in sodium preference among 40 Wistar male rats (180-220 g). Sodium preference was measured as mean spontaneous ingestion of $1.5 \% \mathrm{NaCl}$ solution during a test period of 12 days. The relevant tissues included the olfactory bulb (OB), the posterior and anterior lobes of the pituitary gland (PP and AP, respectively), the median eminence (ME), the medial basal hypothalamus $(\mathrm{MBH})$, and the region anteroventral to the third ventricle $\left(\mathrm{AV}_{3} \mathrm{~V}\right)$. We also measured ANP content in the right (RA) and left atrium (LA) and plasma. The concentrations of ANP in the $\mathrm{OB}$ and the $\mathrm{AP}$ were correlated with sodium ingestion during the preceding $24 \mathrm{~h}$, since an increase of ANP in these structures was associated with a reduced ingestion and vice-versa (OB: $r=-0.3649$, $\mathrm{P}<0.05$; AP: $\mathrm{r}=-0.3291, \mathrm{P}<0.05)$. Moreover, the AP exhibited a correlation between ANP concentration and mean $\mathrm{NaCl}$ intake $(r=-0.4165, P<0.05)$, but this was not the case for the $\mathrm{OB}(\mathrm{r}=0.2422)$. This suggests that differences in sodium preference among individual male rats can be related to variations of AP ANP level. Earlier studies indicated that the $\mathrm{OB}$ is involved in the control of $\mathrm{NaCl}$ ingestion. Our data suggest that the OB ANP level may play a role mainly in day-today variations of sodium ingestion in the individual rat.
\end{abstract}

Key words

- Sodium chloride intake

- Sodium chloride preference

- Atrial natriuretic peptide
Wistar rats usually exhibit a high variability in spontaneous sodium intake when a sodium chloride solution and water are offered simultaneously $(1,2)$. This salt preference is innate, and manipulation of food salt content fails to influence salt preference $(3,4)$. Data from previous studies suggest that the brain atrial natriuretic peptide (ANP)ergic system is involved in the regulation of arterial pressure, sodium excretion and sodium chloride ingestion (5,6). Antunes-Rodrigues et al. (7) showed that intracerebroventricular injection of ANP inhibited sodium chloride intake in Wistar rats. Some studies also reported changes in ANP content of atria and plasma after chronic sodium overload (810). In the present study we determined correlations between innate sodium chloride preference in male Wistar rats and ANP content/concentration in some ANPergic brain 
Figure 1 - Frequency distribution for the average daily intake of $1.5 \% \mathrm{NaCl}$ for 60 male Wistar rats. structures related to the control of sodium intake and excretion, i.e., olfactory bulbs (OB), anterior pituitary (AP), posterior pituitary (PP), median eminence (ME), the region anteroventral to the third ventricle $\left(\mathrm{AV}_{3} \mathrm{~V}\right)$ and medial basal hypothalamus (MBH) $(11,12)$, in the right and left atria (RA and LA, respectively) and in plasma.

Sixty male Wistar rats weighing 180 to $220 \mathrm{~g}$ were placed in individual cages and offered Purina rat chow (sodium and potassium contents: $64.5 \mathrm{mEq} / \mathrm{kg}$ and $115.3 \mathrm{mEq} /$ $\mathrm{kg}$, respectively), $1.5 \% \mathrm{NaCl}$ solution and tap water from calibrated glass tubes. Water and sodium intake were measured daily in the morning and corrected for body weight (measured on days 0,6 and 12). After 12 days forty rats were decapitated and trunk blood was collected into tubes cooled in crushed ice. The tubes contained the following proteolytic enzyme inhibitors: $2 \mathrm{mg}$ EDTA, $20 \mu 11 \mathrm{mM}$ phenylmethylsulfonyl fluoride (Sigma, P-7626), and $20 \mu \mathrm{l} 500 \mu \mathrm{M}$ pepstatin A (Sigma, P-4265). The collected samples were centrifuged at low speed for $20 \mathrm{~min}$, and the plasma was stored at $-20^{\circ} \mathrm{C}$. Aliquots $(100 \mu \mathrm{l})$ were taken to determine sodium concentration in plasma using a flame spectrophotometer. Immunoreactive ANP

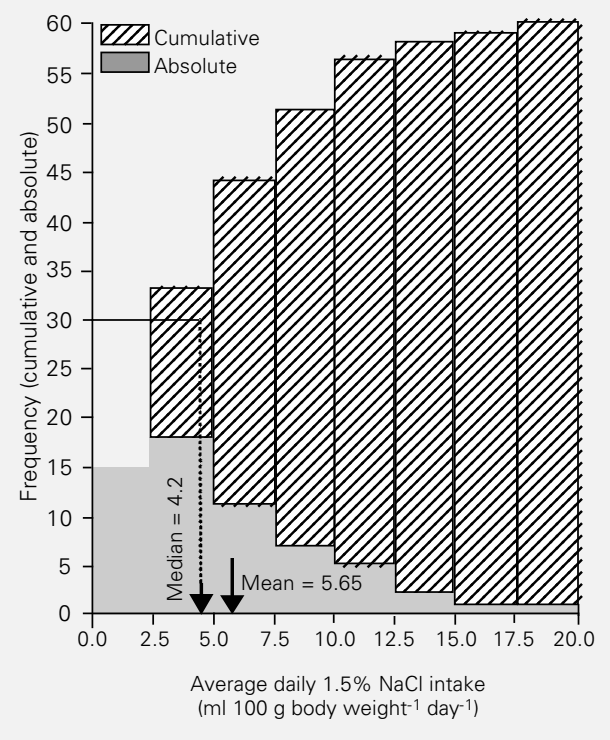

was extracted from $1 \mathrm{ml}$ of plasma with heatactivated Vycor glass beads (Corning No. 7930, Mesh 140) as described by Gutkowska et al. (13), and the lyophilized residue was frozen at $-20^{\circ} \mathrm{C}$. Each sample was resuspended in $500 \mu \mathrm{l}$ ANP buffer $(50 \mathrm{mM}$ potassium phosphate, $\mathrm{pH} 7.4,0.15 \mathrm{M} \mathrm{NaCl}, 0.1 \%$ bovine serum albumin (Sigma, A-7888), $0.1 \%$ Triton $\mathrm{X}-100$, and $0.02 \% \mathrm{NaN}_{3}$ ) and aliquots of $100 \mu \mathrm{l}$ were taken in duplicate for radioimmunoassay. After decapitation and blood collection as described above, AP, PP, $\mathrm{ME}, \mathrm{MBH}, \mathrm{AV}_{3} \mathrm{~V}, \mathrm{OB}, \mathrm{RA}$ and $\mathrm{LA}$ were quickly removed and placed in $0.5 \mathrm{ml} 0.1 \mathrm{M}$ acetic acid containing the same proteolytic enzyme inhibitors used for plasma preparation. The tissues were homogenized using a Polytron. The homogenates were centrifuged at high speed at $4^{\circ} \mathrm{C}$ for $10 \mathrm{~min}$. Aliquots of the supernatant of $50 \mu \mathrm{l}$ for $\mathrm{MBH}, \mathrm{OB}$ and $\mathrm{AV}_{3} \mathrm{~V}$ and $10 \mu \mathrm{l}$ for RA and LA were taken for determination of protein concentration using the method of Lowry. The remaining supernatant was lyophilized and stored at $20^{\circ} \mathrm{C}$ until assay for ANP. Each sample was reconstituted in an appropriate volume of ANP buffer, and aliquots of $100 \mu \mathrm{l}$ were taken for radioimmunoassay (13). The sensitivity and specificity of the ANP radioimmunoassay have been described in detail by Gutkowska et al. (14). We used the least squares method for regression calculation, without and with data transformation by logarithmic, power and exponential functions. The correlation coefficient (r) was used to test significance at the $\mathrm{P}<0.05$ level.

We demonstrated remarkable individual differences in sodium preference in male Wistar rats (see Figure 1). The minimal and maximal values for average sodium chloride intake were 0.6 and $18.75 \mathrm{ml} 100 \mathrm{~g}$ body weight $^{-1}$ day $^{-1}$, respectively, and the range was $18.15 \mathrm{ml} 100 \mathrm{~g}$ body weight ${ }^{-1} \mathrm{day}^{-1}$. The mode, median and average values were 4 , 4.2 and $5.65 \mathrm{ml} 100 \mathrm{~g}$ body weight $^{-1}$ day $^{-1}$, respectively.

The OB and the AP presented variations 
in ANP concentration that were correlated with sodium ingestion during the previous $24 \mathrm{~h}$ (OB: $\mathrm{r}=-0.3649, \mathrm{P}<0.05$ and AP: $\mathrm{r}=$ $-0.3291, \mathrm{P}<0.05)$. The increase in ANP content in these structures was associated with reduced $\mathrm{NaCl}$ ingestion and vice-versa. Only the AP presented variations in ANP content that were correlated with the average ingestion over a 12-day period $(\mathrm{r}=-0.4165$, $\mathrm{P}<0.01)$. For all other tissues the variations in ANP content did not correlate with sodium intake. Moreover, we determined the correlations between ANP content and plasma sodium levels. Increased natremia decreased the ANP content in PP $(\mathrm{r}=$ $-0.6910, \mathrm{P}<0.001)$ and AP $(\mathrm{r}=-0.5179$, $\mathrm{P}<0.001)$, and increased ANP in MBH $(\mathrm{r}=$ $0.4461, \mathrm{P}<0.01)$. We also tested the correlations between ANP content of the atria and plasma ANP, and only the ANP content of the RA presented a negative correlation $(\mathrm{r}=$ $-0.5128, \mathrm{P}<0.001)$ with plasma ANP. The data on the correlations are summarized in Table 1.

Cyclic variations in ingestion of $\mathrm{NaCl}$ solutions for the same individual have been described earlier (15). These variations are more pronounced in females, in which a periodic pattern is related to the estrous cycle. We confirmed the existence of variations for the individual male rat and, in addition, determined differences between individual male rats of the same strain concerning their salt preference.

The OB exerts an inhibitory influence on sodium ingestion, since bulbectomy is associated with an increased sodium ingestion (16). There are reports showing that ANP, pro-ANP and ANP receptors are present in the OB (11). These receptors are localized in the external plexiform layer (17), which contains modulating interneurons that receive impulses originating mainly from the limbic system. The angiotensin receptors are also localized in this layer, which suggests that angiotensin and ANP may have antagonistic physiological actions in the $\mathrm{OB}$, as described for other brain areas (17). ANP of the OB may exert a modulating effect on sodium ingestion in such a way that an increased ANP level facilitates inhibitory impulses to the limbic structures involved in sodium appetite, whereby sodium ingestion becomes reduced. The lack of correlation between the 12-day mean ingestion and OB ANP level implies that this level is related to short-term sodium intake. Consequently, the OB ANP level might be related to the day-to-day variations occurring in the same individual.

The ANP level of the AP was correlated with sodium ingestion, both for the 12-day mean value and for the last 24-h measurement. Earlier reports have described alterations of ANP content in the AP in response

Table 1 - Correlation between ANP content/level in olfactory bulbs (OB), right (RA) and left $(L A)$ atria, anteroventral region of the third ventricle $\left(A V_{3} V\right)$, median eminence $(\mathrm{ME})$, anterior pituitary (AP), posterior pituitary (PP), medial basal hypothalamus (MBH) and plasma versus average daily $1.5 \% \mathrm{NaCl}$ intake, last $24 \mathrm{~h} 1.5 \% \mathrm{NaCl}$ intake and natremia for 40 male Wistar rats.

Simple linear regression as well as logarithmic, power and exponential function transformations were performed, and the best fitting curve was used to test for significance. The sign minus before the $r$ value indicates a negative correlation. n.s., Nonsignificant.

\begin{tabular}{|c|c|c|c|}
\hline $\begin{array}{l}\text { ANP } \\
\text { content/ } \\
\text { level }\end{array}$ & $\begin{array}{l}\text { Last } 24 \mathrm{~h} \\
1.5 \% \mathrm{NaCl} \text { intake } \\
\left(\mathrm{mEq} 100 \mathrm{~g} \mathrm{body}^{-1} \text { daght }^{-1} \text { day }^{-1}\right)\end{array}$ & $\begin{array}{c}\text { Average daily } \\
1.5 \% \mathrm{NaCl} \text { intake } \\
\text { (mEq } 100 \mathrm{~g}^{\mathrm{m} \text { body }} \\
\text { weight }^{-1} \text { day }^{-1} \text { ) }\end{array}$ & $\begin{array}{l}\text { Natremia } \\
(\mathrm{mEq} / \mathrm{l})\end{array}$ \\
\hline $\begin{array}{l}\text { OB } \\
\text { (pg/mg prot) }\end{array}$ & $\begin{array}{c}r=-0.3649 \\
P<0.05\end{array}$ & $\begin{aligned} & r= 0.2422 \\
& \text { n.s. }\end{aligned}$ & $\begin{aligned} & r= 0.1327 \\
& \text { n.s. }\end{aligned}$ \\
\hline $\begin{array}{l}\text { RA } \\
\text { ( } \mu \mathrm{g} / \mathrm{mg} \text { prot) }\end{array}$ & $r=\begin{aligned} r=2765 \\
\text { n.s. }\end{aligned}$ & $\begin{array}{c}r=-0.1767 \\
\text { n.s. }\end{array}$ & $\begin{array}{c}r=-0.0297 \\
\text { n.s. }\end{array}$ \\
\hline $\begin{array}{l}\text { LA } \\
\text { ( } \mu \mathrm{g} / \mathrm{mg} \text { prot) }\end{array}$ & $\begin{array}{c}r=-0.1778 \\
\text { n.s. }\end{array}$ & $\begin{array}{c}r=- \\
\text { n.s. }\end{array}$ & $\begin{array}{c}r=-0.2471 \\
\text { n.s. }\end{array}$ \\
\hline $\begin{array}{l}\mathrm{AV}_{3} \mathrm{~V} \\
\text { (pg/mg prot) }\end{array}$ & $\begin{array}{c}r=-0.2142 \\
\text { n.s. }\end{array}$ & $\begin{array}{c}r=-0.2188 \\
\text { n.s. }\end{array}$ & $\begin{array}{c}r=-0.2012 \\
\text { n.s. }\end{array}$ \\
\hline $\begin{array}{l}\text { ME } \\
\text { (pg/organ) }\end{array}$ & $\begin{array}{c}r=-0.0316 \\
\text { n.s. }\end{array}$ & $\begin{aligned} r= & -0.0615 \\
& \text { n.s. }\end{aligned}$ & $\begin{array}{c}r=-0.1631 \\
\text { n.s. }\end{array}$ \\
\hline $\begin{array}{l}\text { AP } \\
\text { (pg/organ) }\end{array}$ & $\begin{array}{c}r=-0.3291 \\
P<0.05\end{array}$ & $\begin{array}{c}r=-0.4165 \\
P<0.01\end{array}$ & $\begin{array}{c}r=-0.5179 \\
P<0.001\end{array}$ \\
\hline $\begin{array}{l}\text { PP } \\
\text { (pg/organ) }\end{array}$ & $\begin{array}{c}r=-0.1686 \\
\text { n.s. }\end{array}$ & $\begin{aligned} & r= 0.1233 \\
& \text { n.s. }\end{aligned}$ & $\begin{array}{c}r=0.6910 \\
P<0.001\end{array}$ \\
\hline $\begin{array}{l}\mathrm{MBH} \\
\text { (pg/mg prot) }\end{array}$ & $r=\begin{array}{l}r=1835 \\
\text { n.s. }\end{array}$ & $\begin{aligned} & r= 0.1653 \\
& \text { n.s. }\end{aligned}$ & $\begin{array}{c}r=0.4461 \\
P<0.01\end{array}$ \\
\hline $\begin{array}{l}\text { Plasma } \\
\text { (pg/ml) }\end{array}$ & $\begin{array}{c}r=-0.1456 \\
\text { n.s. }\end{array}$ & $\begin{array}{c}r=-0.1491 \\
n . s .\end{array}$ & $\begin{aligned} & r= 0.2758 \\
& \text { n.s. }\end{aligned}$ \\
\hline
\end{tabular}


to manipulation of areas that are involved in the regulation of sodium intake and excretion (12). In spite of this observation, few data are available on the regulation of ANP production and secretion in the AP, which also applies to its site of action (endocrine or paracrine). The sodium preference differences among individual rats might be related to the variations of ANP concentration that we measured in the AP, but further studies are needed to clarify this matter.

The lack of correlation between sodium ingestion and ANP concentrations of plasma or of the atria suggests that the plasma and/or atrial ANP levels are not involved in adaptation to mild sodium overload under the present conditions. Our data are consistent with earlier reports that showed a slight increase in plasma ANP on the first day of sodium overload, whereas after one day of sodium overload no more changes in plasma were detectable (9). The fact that we found an inverse correlation between the plasma ANP level and the ANP level of the right atrium but not of the left atrium suggests that the right atrium is the principal source of ANP under the conditions studied.

\section{Acknowledgments}

We thank M. Holanda and M.V.A.S. Silva for technical assistance and M.L. Glass for critical editing of the manuscript.

\section{References}

1. Carneiro-Leão A (1979). Alterações da ingestão de água e solução de $\mathrm{NaCl}$ causadas pela lesão da área septal e/ou tratamento repetitivo com acetato de desoxicorticosterona em ratos. Master's thesis, Faculdade de Medicina de Ribeirão Preto, Universidade de São Paulo, Ribeirão Preto.

2. Carneiro-Leão $A$ (1986). Controle genético do apetite ao sal. Reunião Anual da Federação de Sociedades de Biologia Experimental (FESBE I), Resumos. São Paulo, 256.

3. Midkiff EE \& Bernstein IL (1983). The influence of age and experience on salt preference of the rat. Developmental Psychobiology, 19: 185-196.

4. Mouw DR, Vandes AJ \& Wagner J (1978). Effects of prenatal and early postnatal sodium deprivation on subsequent adult thirst and salt preference in rats. American Journal of Physiology, 234 (Renal, Fluid and Electrolyte Physiology, 3): F59F63.

5. McCann SM, Franci CR \& AntunesRodrigues J (1989). Hormonal control of water and electrolyte intake and output. Acta Physiologica Scandinavica, 136 (Suppl 583): 1-7.

6. Saper CB, Standaert DG, Currie MG, Schwartz D, Geller D \& Needleman P (1985). Atriopeptin immunoreactive neurons in the brain: presence in cardiovascular regulatory areas. Science, 227: 10471049.
7. Antunes-Rodrigues J, McCann SM \& Samson WK (1986). Central administration of atrial natriuretic factor inhibits saline preference in the rat. Endocrinology, 118: 1726-1728.

8. Lattion AL, Aubert JF, Flückiger JP, Nussberger J, Waeber B \& Brunner HR (1988). Effect of sodium intake on gene expression and plasma levels of ANF in rats. American Journal of Physiology, 255 (Heart and Circulation Physiology, 24): $\mathrm{H} 245-\mathrm{H} 249$.

9. Kato J, Kida O, Nakamura S, Sasaki A, Takigushi K \& Tanaka K (1986). Dissociation between plasma and atrial content of atrial natriuretic polypeptide (ANP) following sodium load in rats. Life Sciences, 39: 2623-2627.

10. Schwarz D, Katsuve NC \& Needleman P (1986). Atriopeptin release in conditions of altered salt and water balance in the rat. Biochemical and Biophysical Research Communications, 137: 922-928.

11. Gutkowska J, Tremblay J, Meyer R, Marcinkiewicz M \& Nemer M (1991). Evidence for atrial natriuretic peptide (ANP) synthesis and the presence of ANP-transducing receptors in the rat olfactory bulb. Journal of Neurochemistry, 57: 18551861.

12. McCann SM, Gutkowska J, Franci CR, Favaretto ALV \& Antunes-Rodrigues $J$ (1994). Hypothalamic control of water and salt intake and excretion. Brazilian Journal of Medical and Biological Research, 27: 865-884.
13. Gutkowska J, Horky K, Thibault G, Januszewicz P, Cantin M \& Genest J (1984). Atrial natriuretic factor is a circulating hormone. Biochemical and Biophysical Research Communications, 125: 315323.

14. Gutkowska J, Thibault $P$, Januszewicz $P$, Cantin M \& Genest J (1984). Direct radioimmunoassay of atrial natriuretic factor. Biochemical and Biophysical Research Communications, 122: 593-601.

15. Covian MR, Antunes-Rodrigues J, Gentil CG, Saad WA, Camargo LA \& Silva Neto CR (1975). Central control of salt balance. In: Morgenson GJ \& Calaresu FR (Editors), Neural Integration of Physiological Mechanisms and Behavior (JAF Stevenson Memorial Volume). University of Toronto Press, Toronto, 267-285.

16. Chiaraviglio E (1969). Effect of lesions in the septal area and olfactory bulbs on sodium chloride intake. Physiology and Behavior, 4: 693-697.

17. Mendelsohn FAO, Allen AM, Chai SY, Sexton PM \& Figdor R (1987). Overlapping distribution of receptors for atrial natriuretic peptide and angiotensin II visualized by in vitro autoradiography: morphological basis of physiological antagonism. Canadian Journal of Physiology and Pharmacology, 65: 1517-1521. 